\title{
Destructive and Non-destructive Tests of Bamboo Oriented Strand Board under Various Shelling Ratios and Resin Contents ${ }^{1}$
}

\author{
Sena Maulana, ${ }^{2,6}$ Yuarsa Gumelar ${ }^{2}$ - Adesna Fatrawana ${ }^{7} \cdot$ Muhammad Iqbal Maulana $^{2}$ • \\ Wahyu Hidayat ${ }^{3} \cdot$ Ihak Sumardi $^{4} \cdot$ Nyoman Jaya Wistara $^{2} \cdot$ Seung Hwan Lee ${ }^{5}$. \\ Nam Hun Kim ${ }^{5, \dagger} \cdot$ Fauzi Febrianto ${ }^{2, \dagger}$
}

\begin{abstract}
The objectives of this study were to evaluate the effects of shelling ratio and resin content on the properties of bamboo oriented strand board (BOSB) from betung (Dendrocalamus asper) and to determine the correlation between the results of dynamic and static bending tests. Strands were steam-treated at $126{ }^{\circ} \mathrm{C}$ for $1 \mathrm{~h}$ under $0.14 \mathrm{MPa}$ pressure and followed by washing with $1 \% \mathrm{NaOH}$ solution. Three-layer BOSB with the core layer perpendicular to the surface was formed with shelling ratios (face:core ratio) of 30:70; 40:60; 50:50; 60:40 and binded with 7\% and 8\% of phenol formaldehyde $(\mathrm{PF})$ resin with the addition of $1 \%$ of wax. The evaluation of physical and mechanical properties of BOSB was conducted in accordance with the JIS A 5908:2003 standard and the results were compared with CSA 0437.0 standard for commercial OSB (Grade O-1). Non-destructive testing was conducted using Metriguard Model 239A Stress Wave Timer which has a wave propagation time from 1 to 9,999 $\mu$ s and a resolution of $1 \mu \mathrm{s}$. BOSB with $8 \%$ resin content showed better physical and mechanical properties than those with $7 \%$ resin content. The increase of the face layer ratio improved the strength of BOSB in parallel direction to the grain. The results suggested that shelling ratio of 50:50 could be used as a simple way to reduce PF resin requirements from $8 \%$ to $7 \%$ and to meet the requirements of CSA 0437.0 standard. The results of non-destructive and destructive tests showed a strong correlation, suggesting that non-destructive test can be used to estimate the bending properties of BOSB.
\end{abstract}

Keywords: bamboo, Dendrocalamus asper, bamboo oriented strand board, non-destructive test, resin content, shelling ratio

\footnotetext{
${ }^{1}$ Date Received May 3, 2019, Date Accepted July 15, 2019

2 Department of Forest Products, Faculty of Forestry, Bogor Agricultural University, IPB Dramaga Campus, Bogor, 16680, Indonesia

${ }^{3}$ Department of Forestry, Faculty of Agriculture, Lampung University, Jalan Sumantri Brojonegoro 1, Bandar Lampung 35145, Indonesia

${ }^{4}$ School of Life Sciences and Technology, Bandung Institute of Technology, Jalan Ganesha 10 Bandung 40132, Indonesia

${ }^{5}$ Department of Forest Biomaterials Engineering, College of Forest and Environmental Science, Kangwon National University, Chuncheon 24341, Republic of Korea

${ }^{6}$ Forestry Engineering, Faculty of Production and Industrial Technology, Institut Teknologi Sumatera (ITERA), Lampung Selatan 35551, Indonesia

${ }^{7}$ Forestry Study Program, Faculty of Agriculture, Khairun University, Ternate City, Nort Maluku 97721, Indonesia

$\dagger$ Corresponding author: Fauzi Febrianto (e-mail: febrianto76@yahoo.com, ORCID: 0000-0002-0964-2179)

† Corresponding author: Nam Hun Kim (e-mail: kimnh@kangwon.ac.kr, ORCID: 0000-0002-4416-0554)
} 
Sena Maulana $\cdot$ Yuarsa Gumelar $\cdot$ Adesna Fatrawana $\cdot$ Muhammad Iqbal Maulana $\cdot$ Wahyu Hidayat Ihak Sumardi · Nyoman Jaya Wistara - Seung Hwan Lee • Nam Hun Kim • Fauzi Febrianto

\section{INTRODUCTION}

Bamboo is one of the fastest growing grass species that widely distributed in Indonesia. In 2017, the production of bamboo in Indonesia reached 14 million stems which were mainly supplied from Bali, Nusa Tenggara, Java, Sumatera, and Celebes Islands (Statistics Indonesia 2017). Priyanto and Abdulah (2014) reported that bamboo forests in Indonesia is around 2 million ha, consisting of 0.72 million ha of bamboo natural forests and 1.40 million ha of plantation forests.

Bamboo is a promising material to be used as substitute to wood-based products due to its advantages such as good strength, hardness, machining, and finishing properties. Febrianto et al. (2017) reported that mechanical properties of bamboo in parallel direction to the grain were superior compared to wood. Zhang et al. (2018) reported on the dimensional stability and mechanical properties of bamboo fiber-based composites. The results showed the positive linear relations between density and dimensional stability at hot- and cold pressing, indicating that the width swelling ratio, thickness swelling ratio and water absorption ratio decreased with an increase in the density of the composites. In addition, bamboo was also fast growing, abundant in its native range and light weight. Lobovikov et al. (2007) stated that bamboo had a relatively light weight compared to wood, hence making the harvesting operation easier. van der Lugt et al. (2006) and Nurdiah (2016) shows that bamboo has the potential to compete with other materials such as wood, iron, and mild steel. Therefore, the utilization of bamboo as a renewable and sustainable substitute to wood products could also contribute on reducing forest deforestation (Lobovikov et al., 2009; Kuehl et al., 2018). Apart from its advantages, bamboo has some disadvantages when used as material for construction that require wide dimension. This is due to the limited diameter and thickness of bamboo compared to wood, hence limiting its application (Febrianto et al., 2017).

Conversion of bamboo into composite panel products could be used as the solution to this problem. Oriented strand board (OSB) is one of the promising composite panel products that could adapt the raw material characteristics of bamboo. The research showed that using similar resin content of methylene diphenyldiisocyanate (MDI), bamboo OSB (BOSB) (Adrin et al., 2013; Febrianto et al., 2015; 2012) had better properties compared to OSB from mangium (Acacia mangium) and sentang (Melia excelsa) woods (Febrianto et al., 2009; Iswanto et al., 2010).

Generally, bamboo has higher carbohydrate content than wood. Therefore, it is more susceptible to powder post beetles, fungi and termites attacks (Febrianto et al., 2013; 2014; Zhang, 1995). Extractives also have a negative effect on the gluing process (Nussbaum and Sterley, 2002). Steam pretreatment on betung (Dendrocalamus asper) and andong (Gigantochloa pseudoarundinaceae) bamboo strands with $8 \%$ (phenol formaldehyde) PF resin could improve the dimensional stability and mechanical properties (Febrianto et al., 2013; Maulana et al., 2017). Furthermore, Fatrawana et al. (2019) steam-treated bamboo strands followed by washing with $1 \%$ sodium hydroxide solution prior to manufacturing BOSB with a shelling ratio (face:core) of 67:33, resulting in the change of the chemical components and the increase of dimensional stability and mechanical properties of BOSB. However, the shelling ratio resulted in a large difference between bending strength properties in parallel and perpendicular directions to the grain. Therefore, determining the optimum setting of shelling ratio is needed to achieve the targeted bending strength. Recent studies showed that a decrease of shelling ratio resulted in an increase of board strength in perpendicular direction and a decrease of strength in parallel direction to the grain (Avramidis and Smith, 1989; Chen et al., 2008; Maulana et al., 2016; Pichelin 
et al., 2001; Saad and Hilal, 2012, Seo et al., 2018; Suzuki and Takeda, 2000).

The mechanical properties of BOSB is generally evaluated using destructive test method, particularly static bending test. Destructive test method is easy to carry out, easier to interpret and yields more information, hence it is more widely used and applied in many standards for bending determination (Machek et al., 2001; Oh, 2018). However, the testing is relatively slow and the specimens cannot be used again after the testing (Sakshi, 2018). In the modern industry, rapid method as dynamic or non-destructive test method was developed and it has become a vital part of the quality control process (Sakshi, 2018). Determination of mechanical properties using nondestructive testing method has been carried out on wood composites and shown good correlation with the results of destructive testing method for measuring bending properties (Yang et al., 2017; Karlinasari et al., 2010; Fagan and Bodig, 1985; Pellerin and Morschauser, 1974; Ross, 1984; Ross and Pellerin, 1988). However, scientific reports on the non-destructive test of BOSB bonded with PF resin are still limited. Consequently, the objectives of this study were to evaluate the effects of shelling ratio and resin content on the physical and mechanical properties of BOSB and to determine the correlation between the results of dynamic and static bending tests.

\section{MATERIALS and METHODS}

\subsection{Materials}

Twenty-five culms of 4-year-old betung bamboo (Dendrocalamus asper) were collected from Sukabumi, West Java, Indonesia. Their average density was 0.57 $\mathrm{g} \mathrm{cm}^{-3}$. Bamboo culms were converted into strands as the target length, width, and thickness of 70, 25, and $0.5 \mathrm{~mm}$, respectively, by using a sharp knife. Samples of one hundred strands were randomly taken to determine strand geometry as slenderness ratio (ratio between strand length and thickness) and aspect ratio (ratio between strand length and width) which was calculated according to a method described by Maloney (1993). PF resin with solid content of $42 \%$ and wax were purchased from the Palmolite Adhesive Company in Indonesia.

\subsection{Methods}

\subsubsection{Strand treatment}

Strands were steam-treated in autoclave at $126{ }^{\circ} \mathrm{C}$ under pressure of $0.14 \mathrm{MPa}$ for $1 \mathrm{hr}$. The steam-treated strands were then washed with $1 \%$ sodium hydroxide solution. The strands were subsequently air dried for a week and oven dried at $60-80{ }^{\circ} \mathrm{C}$ for 36 hours until reaching moisture content of less than $5 \%$.

\subsubsection{BOSB preparation}

BOSBs with the dimensions of $30 \mathrm{~cm}$ (length) $\times$ $30 \mathrm{~cm}$ (width) $\times 0.9 \mathrm{~cm}$ (thickness) were manufactured with a target density of $0.7 \mathrm{~g} \mathrm{~cm}^{-3}$. PF resin with a solid content of $42 \%$ and resin content of $7 \%$ and $8 \%$ was used as a binder with $1 \%$ wax addition. The resin and wax were mixed with strands and divided into face, core, and back layers with perpendicular arrangement to each other. The shelling ratios were set to be $30: 70$, 40:60, 50:50, and 60:40. The board was hot-pressed at $135{ }^{\circ} \mathrm{C}$ with a specific pressure of $2.45 \mathrm{MPa}$ for $9 \mathrm{~min}$.

\subsubsection{Board evaluation}

The evaluation of physical and mechanical properties of BOSB was conducted in accordance with the JIS A 5908: 2003 standard (JIS, 2003). All samples were conditioned at 25 to $30{ }^{\circ} \mathrm{C}$ and 60 to $65 \% \mathrm{RH}$ for 2 weeks prior to the testing. The physical properties such as density, moisture content, water absorption, and thickness swelling were evaluated. The evaluated 
Sena Maulana - Yuarsa Gumelar $\cdot$ Adesna Fatrawana $\cdot$ Muhammad Iqbal Maulana $\cdot$ Wahyu Hidayat Ihak Sumardi $\cdot$ Nyoman Jaya Wistara $\cdot$ Seung Hwan Lee $\cdot$ Nam Hun Kim • Fauzi Febrianto

mechanical properties were internal bonding (IB) and bending strengths in parallel and perpendicular directions to the grain including static modulus of elasticity (MOEs) and modulus of rupture (MOR). Non-destructive testing as dynamic MOE (MOEd) test was also conducted in accordance with Yang et al. (2017). Non-destructive testing was performed using Metriguard Model 239A Stress Wave Timer which has a wave propagation time from 1 to 9,999 microseconds with a resolution of 1 microsecond. The distance of two points for sonic propagation time measurement was $18 \mathrm{~cm}$. Propagation time was used to determine the stress wave velocity and be converted to MOEd.

\subsubsection{Data analysis}

The design of the experiment was completely randomized with two factors: resin content (two levels) and shelling ratio (four types), resulting in a total of eight possible treatment combinations. Each treatment was carried out in three replications. The data obtained were analyzed statistically by using analysis of variance (ANOVA) followed by Duncan's multiple range test to determine significant difference of variables within each factor and the interaction between the factors (Steel and Torrie, 1995). All parameters measured were compared to those of the CSA O437.0 (2011) (Grade O-1) standard for OSB panels (SBA 2005).

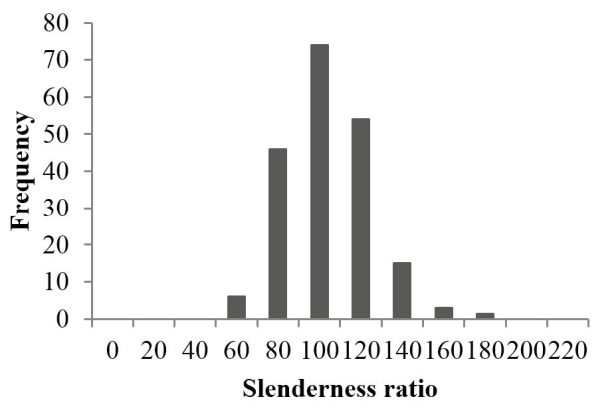

\section{RESULTS and DISCUSSION}

\subsection{Strand geometry}

The quality of strands can be reflected from its slenderness ratio and aspect ratio. According to Marra (1992), strand geometry is one of the main factors that influence the strength of strand board. The overall slenderness ratios ranged from 60 to 180 with the distribution as shown in Fig. 1. Strands for board production were randomly selected and the overall slenderness ratios had sufficient length to produce satisfactory board, showing an average value of 93.6 which was classified as a high slenderness ratio (Febrianto et al., 2015). Maloney (1993) stated that strand with high slenderness ratio attributed to a satisfying contact between strands and could produce a strong board. The results also showed an average aspect ratio of 3.71 with the distribution as shown in Fig. 1. A minimum aspect ratio value of 3 is needed to produce composite panel with a satisfactory strength property (Kuklewski et al., 1985). Juliana et al. (2012) also stated that aspect ratio is one of the important factors for achieving high MOE.

\subsection{Physical properties of BOSB}

The result showed that BOSBs manufactured met the target density with homogeneous values, ranging

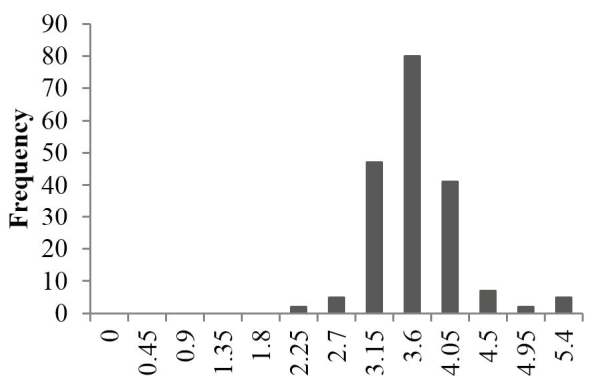

Aspect ratio

Fig. 1. Slenderness ratio and aspect ratio of betung bamboo strands. 
Table 1. Physical properties of BOSB manufactured at various shelling ratio and resin content

\begin{tabular}{cccccc}
\hline $\begin{array}{c}\text { Adhesive content } \\
(\%)\end{array}$ & $\begin{array}{c}\text { Shelling ratio } \\
\text { (face:core) }\end{array}$ & $\begin{array}{c}\text { Density } \\
\left(\mathrm{g} \mathrm{cm}^{-3}\right)\end{array}$ & $\begin{array}{c}\text { MC } \\
(\%)\end{array}$ & $\begin{array}{c}\text { WA } \\
(\%)\end{array}$ & $\begin{array}{c}\text { TS } \\
(\%)\end{array}$ \\
\hline \hline & $30: 70$ & $0.71 \pm 0.00 \mathrm{~A}$ & $10.69 \pm 1.07 \mathrm{~A}$ & $31.36 \pm 1.84 \mathrm{BC}$ & $3.43 \pm 0.50 \mathrm{~B}$ \\
7 & $40: 60$ & $0.71 \pm 0.01 \mathrm{~A}$ & $10.50 \pm 0.06 \mathrm{~A}$ & $29.89 \pm 1.57 \mathrm{~B}$ & $3.91 \pm 0.09 \mathrm{C}$ \\
& $50: 50$ & $0.70 \pm 0.00 \mathrm{~A}$ & $10.49 \pm 0.10 \mathrm{~A}$ & $30.07 \pm 2.46 \mathrm{~B}$ & $3.78 \pm 0.09 \mathrm{BC}$ \\
& $60: 40$ & $0.71 \pm 0.00 \mathrm{~A}$ & $10.78 \pm 0.16 \mathrm{~A}$ & $29.94 \pm 3.34 \mathrm{AB}$ & $3.37 \pm 0.42 \mathrm{~B}$ \\
\hline & $30: 70$ & $0.70 \pm 0.00 \mathrm{~A}$ & $10.61 \pm 0.65 \mathrm{~A}$ & $27.50 \pm 1.78 \mathrm{~A}$ & $2.59 \pm 0.31 \mathrm{~A}$ \\
& $40: 60$ & $0.70 \pm 0.01 \mathrm{~A}$ & $10.30 \pm 0.78 \mathrm{~A}$ & $29.31 \pm 1.03 \mathrm{AB}$ & $2.58 \pm 0.09 \mathrm{~A}$ \\
& $50: 50$ & $0.70 \pm 0.00 \mathrm{~A}$ & $10.23 \pm 0.39 \mathrm{~A}$ & $26.85 \pm 0.75 \mathrm{~A}$ & $2.76 \pm 0.21 \mathrm{AB}$ \\
& $60: 40$ & $0.70 \pm 0.00 \mathrm{~A}$ & $10.39 \pm 0.39 \mathrm{~A}$ & $27.06 \pm 2.03 \mathrm{~A}$ & $2.54 \pm 0.15 \mathrm{~A}$ \\
\hline CSA 0437.0 (Grade O-1) Standard & na & na & na & 15 \\
\hline
\end{tabular}

Notes: na $=$ not available. The means are averages of 3 replicates. Numbers in parenthesis are standard deviations. Means within a column followed by the same capital letter are not significantly different at $5 \%$ significance level using Duncan's multiple range test.

from $0.70-0.71 \mathrm{~g} \mathrm{~cm}^{-3}$ (Table 1). The moisture content of boards also has homogeneous valued, ranging from $10.23-10.69 \%$. Statistical analysis showed that resin content and shelling ratio did not have a significant effect on density and moisture content. The dimensional stability of the BOSBs was reflected by its water absorption and thickness swelling values. The values of water absorption and thickness swelling ranged from 26.85-31.36\% and 2.54-3.91\%, respectively. All BOSBs manufactured at different resin contents and shelling ratios were well corresponded to CSA O437.0 (2011) (Grade O-1) standard for OSB panels, showing overall value of less than $15 \%$. The results of the statistical analysis showed that resin content gave a big significant effect on water absorption and thickness swelling values. The dimensional stability of BOSB manufactured with $8 \% \mathrm{PF}$ resin was superior than using $7 \% \mathrm{PF}$ resin. In contrast, shelling ratio and the resin content did not give a big effect on the water absorption and thickness swelling values.

Higher resin content commonly attributes to a better the dimensional stability with the lower water absorption and thickness swelling values. According to Zhang et al. (2007) and Halligan (1970), resin level, wax, particle geometry, board density, grain direction, blending efficiency, and pressing conditions affects on water uptake behavior of strands. Lower resin content led to more water accessibility and then decreasing the dimensional stability of strand board (Zhang et al., 2007). Febrianto et al. (2015) reported that BOSB of andong (Gigantochloa pseudoarundinaceae), betung (Dendrocalamus asper) and ampel (Bambusa vulgaris) bamboos with resin content of 5\% MDI had better dimensional stability compared to 3 and $4 \%$. Resin penetrated into the cell lumen and other parts of the bamboo strands, reducing the void parts, so that reduce the water uptake capacity of the boards (Febrianto et al., 2015; Barbuta et al., 2011). Increasing resin content in boards improved the bonding between strands which should improve dimensional stability (Kelly, 1977; Liu and McNatt, 1991). Avramidis and Smith (1989) reported that increasing resin content resulted in improved physical properties of the OSB. According to Maraghi et al. (2018), increasing the resin content might be possible to have resin coating on strand which improved the dimensional stability. The increase of bonding between strands will decrease void part and prevent the penetration of water molecules. 
Sena Maulana - Yuarsa Gumelar $\cdot$ Adesna Fatrawana $\cdot$ Muhammad Iqbal Maulana $\cdot$ Wahyu Hidayat Ihak Sumardi $\cdot$ Nyoman Jaya Wistara $\cdot$ Seung Hwan Lee $\cdot$ Nam Hun Kim • Fauzi Febrianto

\subsection{Mechanical properties of BOSB}

The MOR values in parallel and perpendicular directions to the grain were ranging from 12.34-34.80 and 13.65-29.11 MPa, respectively (Fig. 2). The results showed that resin content and shelling ratio significantly affected MOR, while the correlation between resin content and shelling ratio was not significantly affected the MOR. The MOEs values in parallel and perpendicular directions to the grain ranged from 3,102-7,438 MPa and 1,094-3,738 MPa, respectively (Fig. 3). Statistical analysis showed that resin content and shelling ratio significantly affected the MOEs, while the correlation between shelling ratio and resin content was not significantly affected the MOEs value. The results showed that the MOR and MOE values of BOSB manufactured using 8\% PF resin with shelling ratios of $40: 60 ; 50: 50$; and $60: 40$ met the entire requirement of CSA O437.0 (Grade O-1) standard for OSB panels (SBA 2005). However, when using 7\% PF resin, only the MOR and MOE values of BOSBs manufactured with shelling ratio of 50:50 that met the requirement of CSA O437.0 (Grade O-1) standard for OSB panels. $\square 30: 70 \square 40: 60$ 囚50:50 国60:40

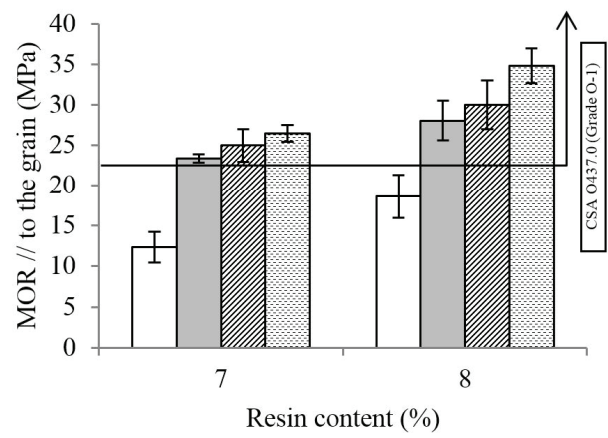

(a) $\square 30: 70 \quad \square 40: 60 \quad$ Ð50:50 因60:40

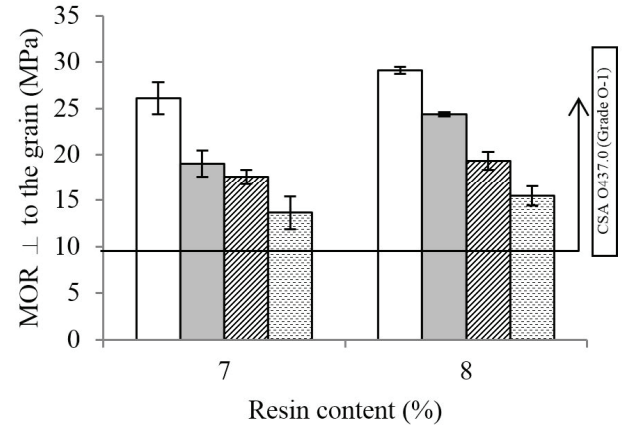

(b)

Fig. 2. The MOR values of BOSB manufactured under different shelling ratio and resin content in: (a) parallel direction to the grain, and (b) perpendicular direction to the grain.

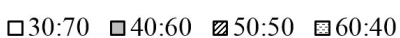

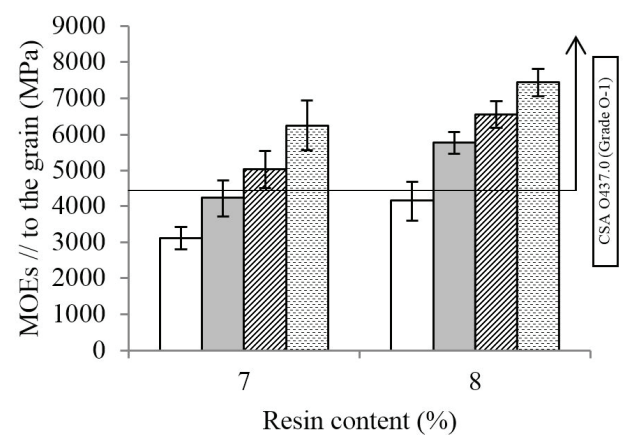

(a)

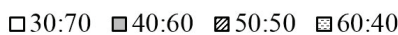

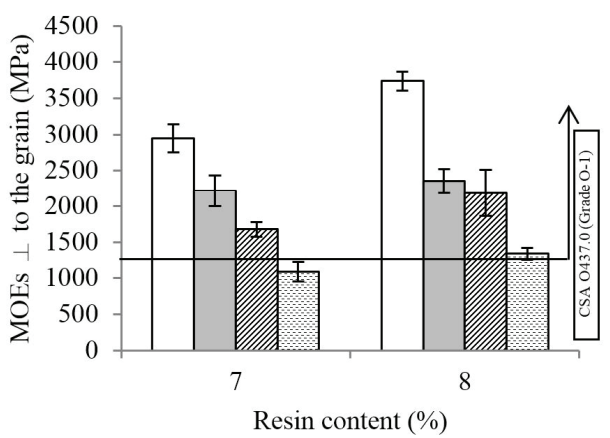

(b)

Fig. 3. The MOEs values of BOSB manufactured under different shelling ratio and resin content in: (a) parallel direction to the grain, and (b) perpendicular direction to the grain. 
Increasing resin content commonly increased MOE values in parallel and perpendicular directions to the grain. The mechanical properties of the BOSB with 8\% PF resin were superior compared to those with $7 \%$ PF resin. Maloney (1993) stated that mechanical properties were affected by resin content and type of resin. The higher resin content facilitated the more interstrands bonding. In addition, Barbuta et al. (2011), Febrianto et al. 2015 and Guntekin and Karakus (2008) reported that increasing resin content increased the mechanical properties of OSB. Sun et al. (2018) also reported the improvement of mechanical properties with increasing PF resin concentration in BOSB from Dendrocalamus giganteus. Avramidis and Smith (1989) reported similar results that MOR and MOE value of OSB from mixture of eastern white pine (Pinus strobus), hemlock (Tsuga canadensis), and aspen (Populus tremuloides) were increased with increasing PF resin content in the range 3-6\%. Lin et al. (2008) revealed that the improvement of the mechanical properties (i.e., MOE, MOR) was achieved by increasing resin content, but decreased with increasing wax content.

Figs. 2 and 3 shows the MOR and MOE of BOSB manufactured under different shelling ratio and resin content in parallel direction to the grain and perpendicular direction to the grain. The increase of shelling ratio increased MOR and MOE of BOSB in parallel direction to the grain, vice versa in perpendicular direction to the grain. The similar effect of shelling ratio on bending strength also reported in several previous studies. Avramidis and Smith (1989) reported that wood OSB with shelling ratio of 60:40 has higher bending strength than that with 50:50. Saad and Hilal (2012) revealed that higher composition of bamboo in face/back layers increased bending strength in parallel direction to the grain of OSB manufactured from ater bamboo (Gigantochloa atter) and water hyacinth (Eichhornia crassipes). Suzuki and Takeda (2000) reported that MOE parallel direction to the grain was increased by increasing face layer ratio in OSB manufactured from sugi wood (Cryptomeria japonica). Chen et al. (2008) reported that the increase of face to core ratio improved MOE parallel direction to the grain. The study also showed that the increase of face to core ratio from 54:46 to 66:34 increased the MOE in parallel direction to the grain by $3.7 \%$. Maulana et al. (2016) reported the similar results that the values of bending strength parallel direction to the grain increased with increasing outer layer ratio. The board received maximum press stresses on the face layer and maximum tensile stresses on back layer during bending evaluation. Therefore, a large number of strands in the outer layers in higher shelling ratio may restrain the load. These can explain the increase in MOE by increasing the face layer ratio.

The IB values were ranging from 0.34 and $0.42 \mathrm{MPa}$ (Fig. 4). IB values were significantly affected by resin content, whereas the correlation between resin content and shelling ratio was not significant. The IB values of BOSB with 8\% PF resin were higher than those with 7\% PF resin. According to Wu and Piao (1999), different resin content affected the number of bonds that occur in composite products. Resin penetrated into void in BOSB, resulting in the more bonding between resin and strands. Therefore, IB value can be improved

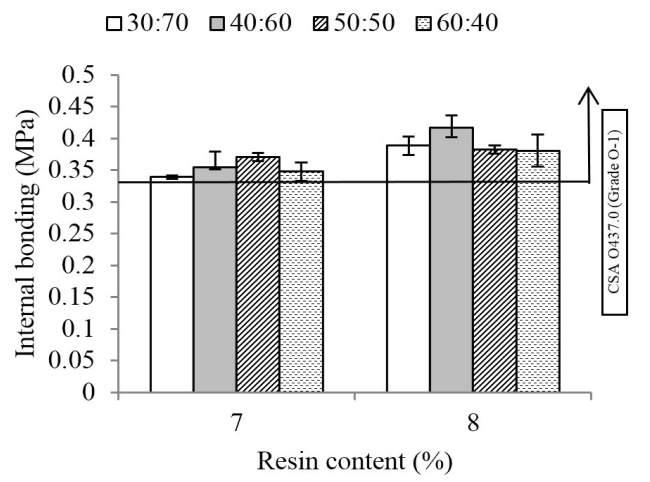

Fig. 4. The IB values of BOSB manufactured under different shelling ratio and resin content. 
Sena Maulana - Yuarsa Gumelar - Adesna Fatrawana - Muhammad Iqbal Maulana - Wahyu Hidayat • Ihak Sumardi $\cdot$ Nyoman Jaya Wistara $\cdot$ Seung Hwan Lee $\cdot$ Nam Hun Kim • Fauzi Febrianto

by increasing the resin content. These phenomena were in line with several studies. Hong et al. (2017) reported that resin content had positive correlation with IB value. IB values were improved by increasing bonding between strands and resin due to the increase of resin content (Febrianto et al., 2009; Febrianto et al., 2015; Gamage et al., 2009; Guntekin and Karakus, 2008; Lin et al., 2008; Zheng et al., 2006).

In our previous study, BOSB from the steam-treated betung bamboo strand followed by washing with $1 \%$ sodium hydroxide and with shelling ratio of 67:33, and bonded with $8 \%$ PF concentration met the entire requirement of CSA O437.0 (Grade O-1) standard (Fatrawana et al. 2019). However, the results of this study showed that when using 7\% PF resin in BOSBs manufactured with shelling ratios of 50:50 could meet the entire requirement of CSA O437.0 (Grade O-1) standard for OSB panels. The results provided a valuable finding, because the shelling ratio of 50:50 reduced the consumption of PF resin by $1 \%$.

\subsection{Dynamic MOE (MOEd)}

Non-destructive test could be used as an efficient evaluation method for mechanical properties of BOSB, especially for a large-scale production. Stress waves velocity by non-destructive testing can be converted to MOEd. The evaluation of MOE using non-destructive test showed that the MOEd values ranged from 4,977-7,505 MPa and 3,280-6,032 Mpa for the MOEd in parallel and perpendicular directions, respectively (Fig. 5). The values of MOEd under various shelling ratio and resin content had similar trend with MOEs. Morales et al. (2013) suggested the possibility using stress wave testing to determine mechanical properties of Brazilian commercial OSB panel. The results showed that resin content and shelling ratio significantly affected the MOEd, while the correlation between resin content and shelling ratio did not significantly affect the MOEd. The value of MOEd in parallel and perpendicular directions to the grain increased with increasing resin content. MOEd in parallel direction to the grain was increased by increasing shelling ratio. Godin (2011) stated that the speed of sound in solid and liquid media is faster than in gas. Therefore, the more resin penetrated will reduce the void space in the boards and increase sonic propagation speed, resulting in the the values of MOEd. However, linear regression is required to determine the precise relationship of non-destructive (i.e., MOEd) and destructive (i.e., MOEs and MOR) $\square 30: 70 \square 40: 60 \quad \square 50: 50 \quad$ 圆60:40

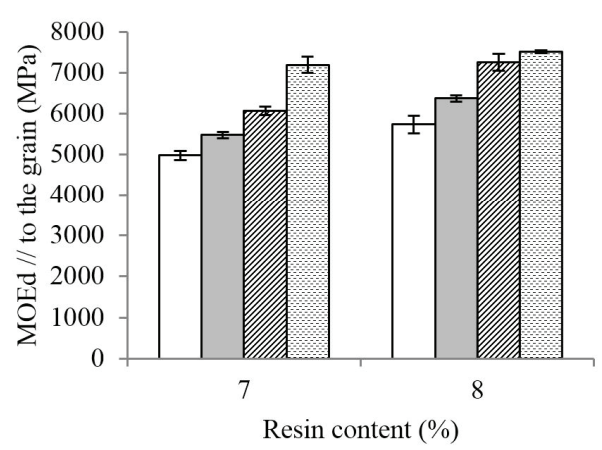

(a)

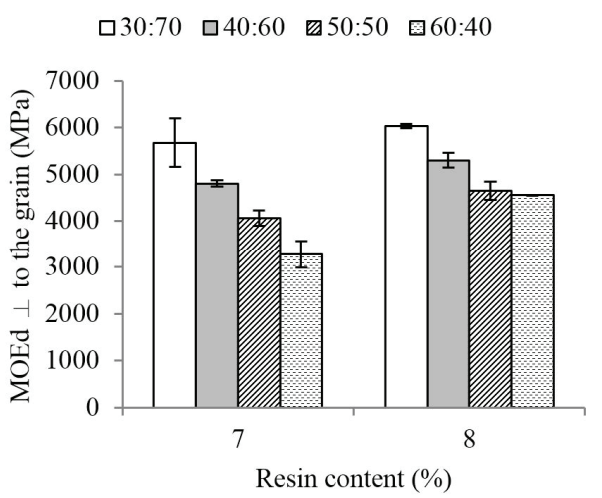

(b)

Fig. 5. The MOEd values of BOSB manufactured under different shelling ratio and resin content in: (a) parallel direction to the grain, and (b) perpendicular direction to the grain. 
for bending specimens.

The linear regression was calculated for all specimens to show the relationship between the results of non-destructive and destructive tests. Non-destructive testing has shown high correlation between dynamic and static in other composite materials (Fagan and Bodig, 1985; Pellerin and Morschauser, 1974; Ross, 1984; Ross and Pellerin, 1988). In this study, a high correlation between static and dynamic test methods for the MOE prediction was achieved, showing correlation coefficient (r) ranging from 0.88-0.93 (Fig. 6). High correlation was also found between the MOEd and MOR in both parallel and perpendicular directions to the grain

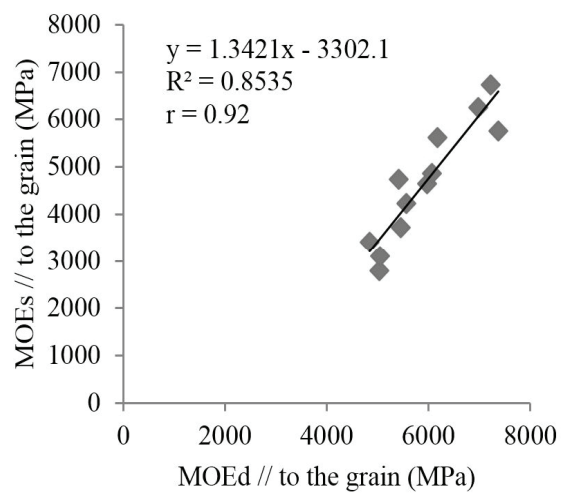

(a)

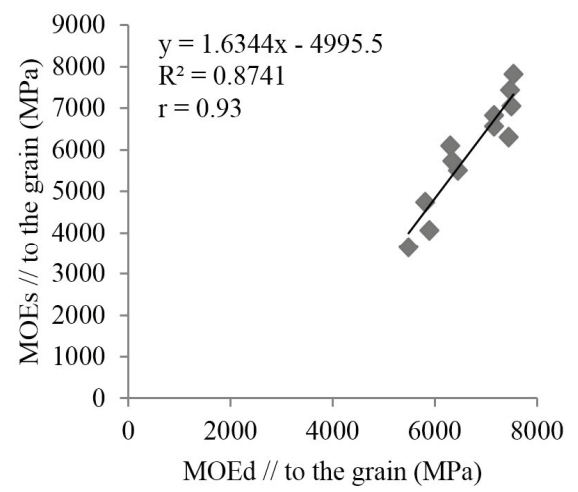

(c)
(Fig. 7). According to EN 326-2 2002 (European Committee for Standardization 2010) the regression equation may be used to calculate the value of independent variables if the calculated value of correlation coefficient is higher than or equal to 0.70 , which is the same as $R^{2}=0.49$. The correlation in this study was better than the result by Han et al. (2006). They reported that the value of $\mathrm{R}^{2}$ were 0.60 and 0.81 for the MOE and 0.58 and 0.82 for the MOR in parallel and perpendicular directions to the grain, respectively. The results suggested that the non-destructive method could provide a consistent results with the results of destructive testing.

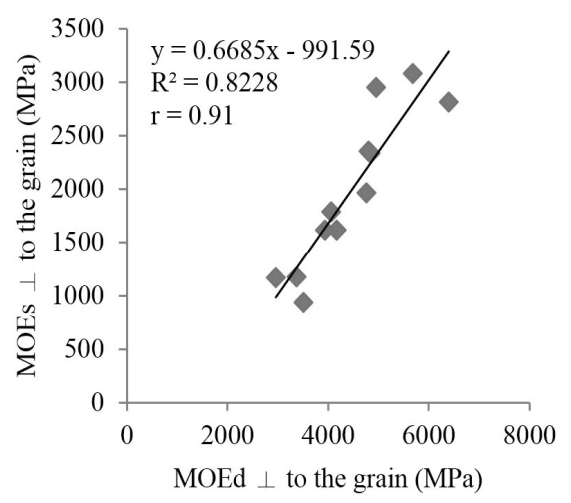

(b)

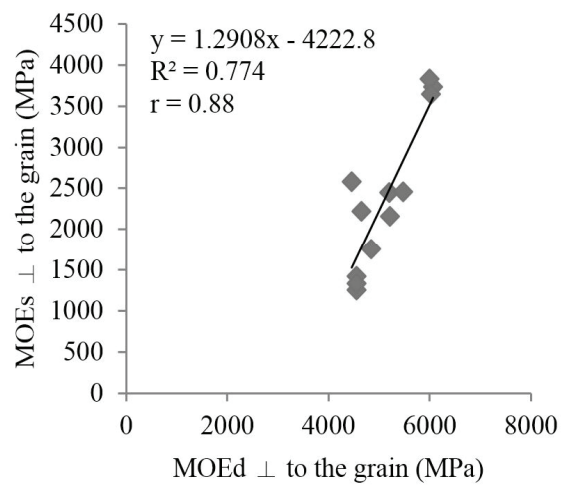

(d)

Fig. 6. Correlation between MOEd and MOEs values of BOSB in: (a) and (b) binded with 7\% $\mathrm{PF}$, (c) and (d) binded with $8 \% \mathrm{PF}$. 
Sena Maulana $\cdot$ Yuarsa Gumelar $\cdot$ Adesna Fatrawana $\cdot$ Muhammad Iqbal Maulana $\cdot$ Wahyu Hidayat Ihak Sumardi $\cdot$ Nyoman Jaya Wistara $\cdot$ Seung Hwan Lee $\cdot$ Nam Hun Kim • Fauzi Febrianto

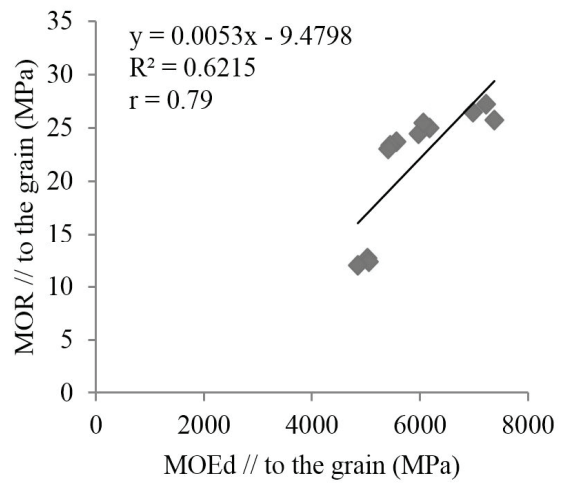

(a)

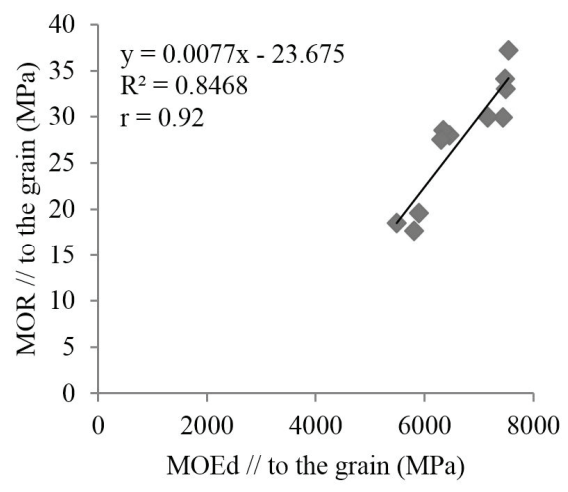

(c)

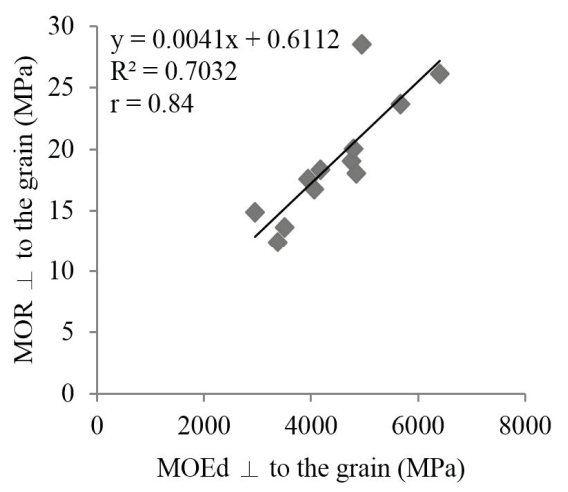

(b)

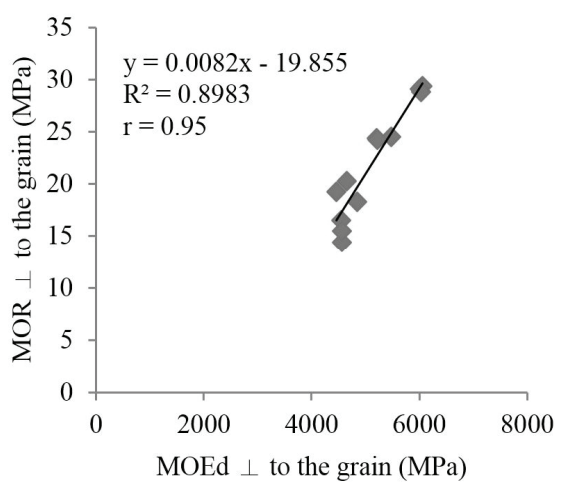

(d)

Fig. 7. Correlation between MOEd and MOR values of BOSB in: (a) and (b) binded with $7 \%$ $\mathrm{PF}$, (c) and (d) binded with 8\% PF.

\section{CONCLUSION}

Strands with high slenderness and aspect ratios were prepared from betung bamboo. BOSB with 8\% PF resin content at various shelling ratios had superior physical and mechanical properties than that with $7 \%$ PF resin content. An increase of shelling ratio increased the bending strength of BOSB in parallel direction to the grain, and vice versa in perpendicular direction to the grain. The shelling ratio of 50:50 could be applied as a simple way to reduce resin consumption from 8 to $7 \%$ and at the same time met the requirements of commercial standards. The results of non-destructive and destructive tests showed a strong correlation, suggesting non-destructive test can be used to estimate the bending properties of BOSB.

\section{ACKNOWLEDGMENT}

We sincerely acknowledge the Doctoral Programme for Outstanding Undergraduate Students Secretariat Research Grant (No. 1503/IT3.11/PN/2018) and Applied Research (National Strategic) Grant (No. 4300/ IT3.L1/PN/2019) from the Directorate of Higher Education (DIKTI), Ministry of Research, Technology, and Higher Education, Republic of Indonesia for to the financial support. This research was also supported by Science and Technology Support Program through 
the National Research Foundation of Korea (NRF) funded by the Ministry of Science and ICT (MSIT) (NRF-2019K1A3A9A01000018) and by Basic Science Research Program through NRF funded by the Ministry of Education(No. 2018R1A6A1A03025582)

\section{REFERENCES}

Adrin, A., Febrianto, F., Sadiyo, S. 2013. Properties of oriented strand board prepared from steam treated bamboo strands under various adhesive combinations. Journal of Tropical Wood Science and Technology 11(2): 109-119.

Avramidis, S., Smith, L.A. 1989. The effect of resin content and face to core ratio on some properties of oriented strand board. Holzforschung 43(2): 131-133.

Barbuta, C., Cloutie, A., Blanchet, P., Yadama, V., Lowell, E. 2011. Tailor made OSB for special application. European Journal of Wood and Wood Products 69(4): 511-519.

Chen, S., Fang, L., Liu, X., Wellwood, R. 2008. Effect of mat structure on modulus of elasticity of oriented strand board. Wood Science and Technology 42: 197-210.

European Committee for Standardization. 2010. EN 326-2 2002: Wood-based panels. Sampling, cutting and inspection. Part 2: Initial type testing and factory production control. Bruselles: European Committee for Standardization.

Fagan, G.B., Bodig, J. 1985. Computer simulation as a nondestructive evaluation tool. In: Proceedings, 5th nondestructive testing of wood symposium; 1985 September 9-11; Pullman, WA. Pullman, WA: Washington State University: 3-37.

Fatrawana, A., Maulana, S., Nawawi, D.S., Sari, R.K., Hidayat, W., Park, S.H., Febrianto, F., Lee, S.H., Kim, N.H. 2019. Changes in chemical components of steam-treated betung bamboo strands and their effects on the physical and mechanical properties of bamboo-oriented strand boards. European Journal of Wood and Wood Products 2019: 1-9. Febrianto, F., Royama, L. I., Hidayat, W., Bakar, E. S., Kwon, J. H., Kim, N.H. 2009. Development of oriented strand board from acacia wood (Acacia mangium Willd.): Effect of pretreatment of strand and adhesive content on the physical and mechanical properties of OSB. Journal of the Korean Wood Science and Technology 37(2): 121-127.

Febrianto, F., Purnamasari, I., Arinana, A., Gumilang, A., Kim, N.H. 2013. Steaming effect on natural durability of bamboo oriented strand board against termites and power post beetle. Journal of Tropical Wood Science and Technology 11(2): 161-169.

Febrianto, F., Gumilang, A., Maulana, S., Busyra, I., Purwantiningsih, A, 2014. Natural durability of five bamboo species against termite and powder post beetle. Journal of Tropical Wood Science and Technology 12(2): 146-156.

Febrianto, F., Jang, J.H., Lee, S.H., Santosa, I.A., Hidayat, W., Kwon, J.H., Kim, N.H. 2015. Effect of bamboo species and resin content on properties of oriented strand board prepared from steam treated bamboo strands. BioResources 10(2): 2642-2655.

Febrianto, F., Sumardi, I., Hidayat, W., Maulana, S. 2017. Oriented Strand Board Superior Material for Structural Building Components. Bogor (ID): IPB Press. (in Bahasa Indonesia)

Gamage, N., Setunge, S., Jollands, M., Hague, J. 2009. Properties of hardwood saw mill residue-based particleboard as affected by processing parameters. Industrial Crops and Products Journal 29: 248-254.

Godin, A.O. 2011. Low-frequency sound transm ission

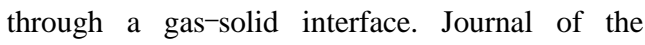
Acoustical Society America 129(2): EL45-EL51. Guntekin, E., Karakus, B., 2008. Feasibility of using eggplant (Solanum melongena) stalks in the production of experimental particleboard, Industrial 
Sena Maulana - Yuarsa Gumelar $\cdot$ Adesna Fatrawana $\cdot$ Muhammad Iqbal Maulana $\cdot$ Wahyu Hidayat Ihak Sumardi $\cdot$ Nyoman Jaya Wistara $\cdot$ Seung Hwan Lee $\cdot$ Nam Hun Kim • Fauzi Febrianto

Crops and Products Journal 27: 354-358.

Halligan, A.F. 1970. A review of thickness swelling in particleboard. Wood Science and Technology 4: 301-312.

Han, G., Wu, Q., Wang, X. 2006. Stress-wave velocity of wood-based panels: effect of moisture, product type, and material direction. Forest Products Journal 56(1): 28-33.

Hong, M.K., Lubis, M.A.R., Park, B.D. 2017. Effect of Panel Density and Resin Content on Properties of Medium Density Fiberboard. Journal of the Korean Wood Science and Technology 45(4): 444-455.

Iswanto, A.H., Febrianto, F., Wahyudi, I., Hwang, W.J., Lee, S.H., Kwon, J.H., Kwon, S.M., Kim, N.H., Kondo, T. 2010. Effect of pre-treatment techniques on physical, mechanical, and durability properties of oriented strand board made from sentang wood. Journal of the Faculty of Agriculture 55(2): 371-377.

Japanese Industrial Standard. 2003. Standards on Particleboard Japanese Standards Association. Tokyo: Japanese Standards Association.

Juliana, A.H., Paridah, M.T., Rahim, S., Azowa, I.N., Anwar, U.M.K. 2012. Properties of particleboard made from kenaf (Hibiscus cannabinus L.) as function of particle geometry Materials \& Design 34: 406-411.

Karlinasari, L., Rahmawati, M., Mardikanto, T.R. 2010. Effect of wood preservation on ultrasonic velocity and bending and compression strength Acacia mangium Wild. Jurnal Teknik Sipil 17(3): 163-170. (in Bahasa Indonesia)

Kelly, M.W. 1977. Critical literature review of relationships between processing parameters and physical properties of particleboard. USDA Forest Serv. Gen. Tech. Rep. FPL-10. Forest Prod. Lab., Madison, WI, USA. pp.65.

Kuehl, A.G., Kuehl, Y., Castillo, J.A. 2018. The potential role of bamboo within the REDD+ mechanism: discussion and review. Journal of Resources Development and Management 42: 47-58.

Kuklewski, K.M., Blankenhorn, P.R., Rishel, L.E. 1985. Comparison of selected physical and mechanical properties of red maple (Acer rubrum L.) and aspen (Populus grandidentata Michx.) flakeboard. Wood and Fiber Science 17(1): 11-21.

Liu, J.Y., McNatt, J.D. 1991. Thickness swelling and density variation in aspen flakeboard. Wood Science and Technology 25: 73-82.

Lin, C., Hiziroglu, S., Kan, S.M., Lai, H.W. 2008: Manufacturing particleboard panels from Betel palm (Areca catechu Linn.). Journal of Materials Processing Technology 197: 445-448.

Lobovikov, M., Lou, Y., Schoene, D., Widenoya, R. 2009. The poor man's carbon sink - Bamboo in climate change and poverty alleviation. FAO Working Document No. 8. FAO, Rome.

Lobovikov, M., Paudel, S., Piazza, M., Ren, H., Wu, J. 2007. World Bamboo Resource: A Thematic Study Prepared in the Framework of the Global Forest Resources Assessment 2005. Rome (IT): Food and Agriculture Organization of the United States.

van der Lugt, P., van den Dobbelsteen, A.A.J.F., Janssen, J.J.A. 2006. An environmental, economic and practical assessment of bamboo as a building material for supporting structures. Construction and Building Materials 20: 648-656.

Machek, L., Militz, H., Alvarez, R.S. 2001. The use of an acoustic technique to assess wood decay in laboratory soil-bed tests. Wood Science and Technology 34:467-472

Maloney, T.M. 1993. Modern Particleboard and Dry-Process Fibreboard Manufacturing. Madison (US): Forest Products Society.

Marra, A.A. 1992. Technology of wood bonding: Principles in practice. Van Nostrand Reinhold, New 
York, NY.

Maulana, S., Busyra, I., Fatrawana, A., Hidayat, W., Sari, R.K., Sumardi, I., Wistara, I.N.J., Lee, S.H., Kim, N.H., Febrianto, F. 2017. Effects of steam treatment on phisycal and mechanical properties of bamboo oriented strand board. Journal of the Korean Wood Science and Technology 45(6): 872-882.

Maulana, S., Purusatama, B.D., Wistara, N.J., Sumardi, I., Febrianto, F. 2016. The effect of steam treatment and shelling ratio on physical and mechanical properties of bamboo oriented strand board. Journal of Tropical Wood Science and Technology 14(2): 136-143. (in Bahasa Indonesia)

Maraghi, M.M.R., Tabei, A., Madanipoor, M. 2018. Effect of board density, resin percentage and pressing temprature on particleboard properties made from mixing of poplar wood slab, citrus branches and twigs of beech. Wood Research 63(4): 669-682.

Morales, E.A.M., Bertolini, M.D.S., Nascimento, M.F.D., Lahr, F.A.R., Ballarin, A.W. 2013. Study of brazilian commercial oriented strand board panels using stress wave. Wood Research 58(2): 295-306.

Nurdiah, E.A. 2016. The potential of bamboo as building material in organic shaped buildings. Procedia - Social and Behavioral Sciences 216: 30-38.

Nussbaum, R.M., Starley, M. 2002. The effect of wood extractive content on glue adhesion and surface wettability of wood. Wood and Fiber Science 34(1): 57 71.

Oh, S.C., 2018. Planar (Rolling) Shear Strength of Structural Panels Using 5-point Bending Test. Journal of the Korean Wood Science and Technology 46(5): 425-436.

Pellerin, R.F., Morschauser, C.R. 1974. Nondestructive Testing of Particleboard. In: Proceedings, 7th Inter- national Particleboard Symposium; 1973 March; Pullman, WA. Pullman, WA: Washington State University.

Pichelin, F., Pizzi, A., Fruhwald, A., Triboulot, P. 2001. Exterior OSB preparation technology at high moisture content. Part 1: Transfer mechanisms and pressing parameters. Holz als Roh-und Werkstoff 59: 256-265.

Priyanto, R., Abdulah, L. 2014. Identification and Design Zone Area for Bamboo Industry Development in Bali. Center for Forest Productivity Research and Development, FORDA, Ministry of Environment and Forestry, Republic of Indonesia.

Ross, R.J. 1984. Stress wave speed and attenuation as pre $\neg$ dictors of the tensile and flexural properties of wood-based particle composites [dissertation]. Washington (US): Pullman, WA: Washington State University.

Ross, R.J., Pellerin, R.F. 1988. NDE of wood-based composites with longitudinal stress waves. Forest Products Journal 38(5): 39-45.

Saad, S., Hilal. 2012. Effect of face-core composition on physical and mechanical properties oriented strand board from bamboo and water hyacinth. J Perennial 8(2): 75-79. (in Bahasa Indonesia).

Sakshi, G. 2018. Comparison of non-destructive and destructive testing on concrete: A review. Trends in Civil Engineering and its Architecture 3(1): 351-357.

SBA, Structural Board Association. 2005. Oriented Strand Board in Wood Frame Construction: U.S. Edition. Structural Board Association.

Seo, J.W., Gang, G.W., Jo, G.H., Park, H. 2018. Study on the physical and mechanical properties of particleboard and oriented strandboard manufactured by Tulliptree (Liriodendron tulipifera L.). Journal of the Korean Wood Science and Technology 46(1): 67-72.

Statistics Indonesia. 2017. Forestry Production 
Sena Maulana - Yuarsa Gumelar - Adesna Fatrawana • Muhammad Iqbal Maulana - Wahyu Hidayat • Ihak Sumardi - Nyoman Jaya Wistara - Seung Hwan Lee · Nam Hun Kim · Fauzi Febrianto

Statistic. Jakarta: Statistics Indonesia. (in Bahasa Indonesia)

Steel, R.G.D., Torrie, J.H. 1995. Prinsip dan Prosedur Statistika Ed ke-2. penerjemah; B. Sumantri, editor. Jakarta (ID): Gramedia Pustaka Utama. Terjemahan dari: Principles and Procedures of Statistics.

Sun, Y., Jiang, Z., Zhang, X., Liu, H. 2018. The effect of culm, age, height, node, and adhesive on the properties of bamboo oriented strand board. Wood and Fiber Science 50(4): 1-9.

Suzuki, S., Takeda, K. 2000. Production and properties of japanesse oriented strand board I: effect of strand length and orientation of strength properties made from sugi OSB. Journal of Wood Science 46: 289-295.

Wu, Q., Piao, P. 1999. Thickness swelling and its relationship to internal bond strength loss of commercial oriented strand board. Forest Products Journal 49(7/8): 50-55.

Yang, Z., Jiang, J., Hse, C.Y., Ru, L. 2017. Assessing the impact of wood decay fungi on the modulus of elasticity of slash pine (Pinus elliottii) by stress wave non-destructive testing. International Biodeterioration \& Biodegradation 117: 123-127

Zhang, Q. 1995. To scientifically and reasonably utilize Chinese bamboo resources. Wood Process. Machin 6(4): 23-32.

Zhang, Y., Jin, J., Wang, S. 2007. Effects of resin and wax on the water uptake behavior of wood strands. Wood and Fiber Science 39(2): 271-278.

Zhang, Y.H., Huang, Y.X., Ma, H.X., Yu, W.J., Qi, Y. 2018. Effect of different pressing processes and density on dimensional stability and mechanical properties of bamboo fiber-based composites. Journal of the Korean Wood Science and Technology 46(4): 355-361.

Zheng, Y., Pan, Z., Zhang, R., Jenkins, B.J., Blunk, S. 2006. Properties of medium-density particleboard from Saline Athel wood, Industrial Crops and Products 23: 318-326. 